\title{
Soviet Union frozen out of Ocean Drilling Program partnership
}

Washington

Plans to make the Soviet Union a full partner in the Ocean Drilling Program (ODP), the next phase of the exploration of the Earth's oceanic crust, may collapse in the face of objections from the US military, to the embarrassment of the sponsoring US agencies, chiefly the National Science Foundation (NSF).

Just one day before a US delegation was to set off for Moscow to sign an agreement making the Soviet Union a full partner in the Ocean Drilling Program, it was told (on 6 February) that it should not leave. The delay was supposed to be temporary, two weeks at most, pending resolution of national security issues raised by the

But in the intervening two months, DoD's position has hardened.Citing worries about national security, DoD is now adamant that Soviet scientists should not be permitted access to the ODP research ship. Once regarded as a small step toward improved relations, Soviet participation in ODP has now become a political hot potato that has reached the very highest levels of US government.

Although the Soviet Union had been an active participant in the Deep Sea Drilling Program, ODP's predecessor, it was not invited to join ODP until 1985. The invitation followed a review by the National Oceanic and Atmospheric Administration, the State Department, the Navy and the interagency Committee on Exchanges (COMEX). The Navy's approval did mention potential difficulties in the area of technology transfer. Late last year the Soviet Union indicated its willingness to join ODP at the beginning of 1987 . Department of Defense (DoD).

But in November, the White House Office of Science and Technology Policy asked for a further review of Soviet participation. The investigation led to some minor revisions in the memorandum of understanding, but raised no serious objections. By then the date for Soviet membership had slipped to 1 March.

The NSF is the lead agency for ODP, providing approximately $\$ 19$ million towards the annual budget. Six international partners - the United Kingdom, West Germany, France, Canada, Japan and the European Science Foundation each provide $\$ 2.5$ million to participate in The Soviets could drill through the sea-bed, and bug our embassies FROM UNDERNEATH!

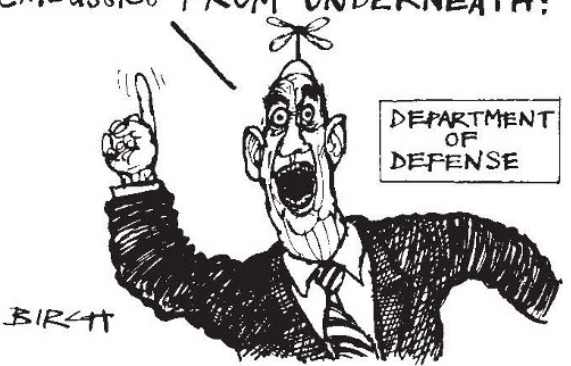

the programme. ODP members contribute scientists to each cruise, and help plan future drilling legs.

Everything seemed in order as a delegation from the State Department, NSF and the Joint Oceanographic Institutions prepared to go to Moscow in February for the signing ceremony. But only days before the ceremony, a letter from the assistant secretary of state for oceans and environmental and scientific affairs John

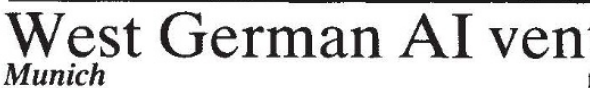

A NEW research centre for artificial intelligence will be set up at the universities of Kaiserslautern and Saarbrücken, it was announced by the West German Minister for Research and Technology, Dr Heinz Riesenhuber, on 27 March. The centre, to be administered by a group of computer companies, will start up in early 1989.

Several companies, including Siemens, Nixdorf and ADV/ORGA, have expressed an interest. The Fraunhofer Society for the Advancement of Applied Research and the Mathematics and Data Processing Research Corporation, both government research institutions, are also expected to take part. The Ministry for Research and Technology (BMFT) will support the projects to be carried out at the centre, which itself will be paid for by the companies and universities.
Negroponte to Navy deputy counsel Hugh O'Neill mentioning that the signing was about to take place set off alarms at DoD. Such was its concern that Secretary of Defense Caspar Weinberger was prevailed upon to ask President Reagan's national security adviser, Frank Carlucci, to intercede and stop the signing.

Both the Navy and the Office of the Secretary of Defense have concluded that giving Soviet scientists access to the technology aboard the ODP drilling ship would be a threat to national security. NSF assistant director William Merrell finds this argument far-fetched. NSF says there are only nine pieces of equipment on board the drilling ship that would require export licences, three of which will soon be removed from the control list.

Merrell says that there could be safeguards on board the ships to prevent unauthorized access if DoD insisted that certain equipment be kept off-limits to Soviet scientists. But DoD is not convinced that such measures would be adequate.

The National Security Council has now asked NSF, DoD and other interested agencies to prepare arguments on whether Soviet participation in ODP should be allowed to proceed. At this point, it would be acutely embarrassing to have to retract an invitation already accepted.

NSF argues that there are good scientific and political reasons to include Soviet scientists in ODP. For instance, NSF says that Soviet participation would help gain permission to drill in areas now out of bounds to ODP. Exploration of the Arctic seabed will be much easier with Soviet help, while Soviet survey ships have already studied the southern Indian Ocean where ODP hopes to go late this year. NSF has also raised the possibility that, if the Soviet Union is denied membership in ODP, it will start its own ocean drilling project and will thus become a competitor for international participants.

NSF is also concerned that rejecting Soviet membership would send a very bad signal for future US-Soviet cooperation. NSF believes it will also cast doubt on US reliability as a scientific leader and participant in global geoscience projects such as the International Geosphere/ Biosphere Program. An agreement on cooperation in space may also be threatened by the muddle over ODP.

NSF is pushing for a decision from the Reagan administration before July, when a large ODP planning meeting will be held in Strasbourg. It is now up to the National Security Council, and ultimately President Reagan, to decide whether national security issues outweigh the damage to international relations that would be caused if the United States reneges on its initiation to the Soviet Union to join ODP. 